\title{
SURVEI POTENSI GAHARU DENGAN SISTEM AGROFORESTRI DI KECAMATAN XIII KOTO KAMPAR, KABUPATEN KAMPAR (STUDI KASUS: DESA PULAU GADANG DAN DESA KOTO MASJID)
}

\author{
Nanang Sulistiono', Enny Insusanty ${ }^{2}$, Azwin $^{2}$ \\ ${ }^{1}$ Mahasiswa Fakultas Kehutanan Universitas Lancang Kuning \\ ${ }^{2}$ Staff Pengajar Fakultas Kehutanan, Universitas Lancang Kuning \\ Email: nanang_sulistiono49@yahoo.com, ennyinsusanty@unilak.ac.id dan azwin@unilak.ac.id
}

\begin{abstract}
This study aims to determine the potential of gaharu with agroforestry system in the village of Pulau Gadang and Koto Masjid Village. The research was conducted in Desa Gadang Village and Koto Masjid Village. This research method is conducted by survey method to gaharu-producing tree and interview to know the agroforestry crop of community and its management. The data collected is then analyzed descriptively. Based on the results of reseach conducted by gaharu plant species is Aquilaria malaccensis with the potential of the plant in the village of Pulau Gadang which is 7 years old as 70 trees, 8 years 920 stems and 9 years as many as 440 stems. Meanwhile, Koto Masjid Village is at the age of planting 7 years as many as 100 stems, 8 years as many as 300 stems and 9 years as many as 400 stems. The potential of gaharu plants in the community of Pulau Gadang Village with an average land area of $1.09 \mathrm{Ha} /$ farmer, the average number of gaharu-producing trees is 84.12 trees / farmers, and the average tree / Ha is 78.03 trees / Ha / farmers. While in Koto Masjid village with average land area is $1.2 \mathrm{Ha} /$ farmer, average number of tree 145,45 trees / farmer, and average tree / Ha counted 68,67 tree / Ha / farmer. The cropping pattern used by the villagers of Pulau Gadang and Koto Masjid is a mixed pattern.
\end{abstract}

Keywords: gaharu, agroforestry, potential

\section{PENDAHULUAN}

Indonesia merupakan negara tercatat adanya data ekspor gaharu dari produsen gaharu terbesar di dunia, Indonesia (Asahan, Budidaya Gaharu, hingga akhir tahun 1990 mampu menghasilkan lebih dari 600 ton per tahun, sejak tahun 2000 produksi terus menurun dan dengan kuota sekitar 300 ton/th hanya mampu terpenuhi antara 10 - 15 \%, bahkan sejak tahun 2004 dengan kuota 50 - 150 ton/th, tidak 2010 dalam Stevanus, 2014). Gaharu merupakan salah satu hasil hutan bukan kayu (HHBK) yang bernilai ekonomi, sosial dan budaya yang sangat tinggi. Dalam Permenhut Nomor P.35/Menhutll/2007, gaharu termasuk dalam daftar 490 jenis Hasil Hutan 
Bukan Kayu (HHBK) nabati yang potensial untuk dikembangkan. Selain itu, gaharu termasuk dalam 5 jenis HHBK yang mendapat prioritas pengembangan, selain jenis rotan, bambu, madu lebah dan sutera (Santoso et al, 2012).

Tingginya permintaan dan harga jual gaharu di pasar internasional serta semakin langkanya tanaman penghasil gaharu di hutan alam, pada sisi lain telah mendorong masyarakat di berbagai daerah melakukan budidaya tanaman pengahasil gaharu seperti di Jambi, Riau, Sumatera Utara, Sumatera Selatan dan Kalimantan Selatan (Squidoo, 2008 dalam Suharti, 2010). Menurut Santoso et al (2012), saat ini penanaman atau budidaya tanaman penghasil gaharu oleh masyarakat, kelompok tani, swasta serta instansi pemerintah telah banyak dilakukan di berbagai wilayah/ kabupaten di seluruh Indonesia.

Salah satu cara yang dilakukan oleh masyarakat saat ini adalah melakukan budidaya gaharu dengan pencampuran tanaman perkebunan maupun tanaman pertanian yang lebih dikenal dengan sistem Agroforestry. Pola tanam gaharu dengan sistem agroforestry sudah mulai banyak dilakukan pada beberapa daerah lain seperti: pencampuran antara tanaman karet dengan Aquilaria malaccensis terdapat di Kabupaten Banyuasin - Sumatera Selatan, Kabupaten Merangin, Jambi (Sofyan et al, 2010), campuran Aquilaria spp dengan tanaman karet atau kakao terdapat di Propinsi Bengkulu (Wiriadinata et al, 2010), dan campuran Aquilaria malaccensis dengan kelapa sawit terdapat di Kabupaten Rokan Hulu-Riau (Suhartiti dan Wahyudi, 2011).

Di Kecamatan XIII koto Kampar, Kabupaten Kampar juga terdapat pola tanam gaharu dengan system argoforestry, Namun masyarakatnya belum mengetahui bagaimana potensi gaharu yang terdapat di daerah tersebut Oleh karena itu, Berdasarkan uraian diatas maka peneliti melakukan penelitian yang berjudul Survey Potensi Gaharu Dengan Sistem Agroforestry di Kecamatan XIII Koto Kampar, Kabupaten Kampar (Studi Kasus: Desa Pulau Gadang dan Desa Koto Masjid). Adapun tujuan penelitian ini adalah untuk mengetahui seberapa besar potensi gaharu dengan sistem agroforestry di Desa Pulau Gadang dan Desa Koto Masjid, Kec. XII Koto Kampar, Kab. Kampar. 


\section{METODE PENELITIAN}

\section{Tempat dan Waktu}

Penelitian ini dilakukan selama \pm 4 bulan yaitu bulan Juni sampai September 2017. Sedangkan lokasi penelitian di Desa Pulau Gadang dan Desa Koto Masjid, Kecamatan XIII Koto Kampar, Kabupaten Kampar.

\section{Bahan dan Alat}

Bahan yang digunakan dalam penelitian adalah tally sheet dan panduan wawancara. Sedangkan alat yang digunakan dalam penelitian ini adalah kamera, alat tulis (seperti: pena, pensil, dan buku), alat ukur diameter (Phi band), kalkulator, dan komputer untuk pengolahan data.

\section{Pengumpulan Data}

Data yang dikumpulkan adalah data primer dan data sekunder. Data primer yang dikumpulkan dari masyarakat pengelola agroforestry diantaranya adalah:

a. Karakteristik responden : nama, umur, jenis kelamin, jumlah anggota keluarga, pendidikan, dan mata pencaharian/pekerjaan lainnya.

b. Informasi lahan : luas kepemilikan lahan, status lahan, potensi (jumlah dan jenis pohon serta diameter) per hektar, dan umur tanaman.

c. Data tentang pengelolaan agroforestry yang dilakukan : (pengadaan benih dan pemeliharaan) pada pohon gaharu.

Pengukuran tanaman agroforestry pada Desa Pulau Gadang dan Desa Koto Masjid dilakukan dengan wawancara. Sementara pengukuran tanaman penghasil Gaharu dilakukan dengan cara sensus. Data sekunder diambil dari berbagai literatur yang ada dan dari instansi-instansi terkait, diantaranya adalah data tentang keadaan umum lokasi penelitian yang meliputi letak dan keadaan geografis, iklim, sarana prasarana yang ada serta keadaan sosial ekonomi masyarakat, dan data sosial ekonomi lain yang terkait.

\section{Pengambilan Sampel}

Sampel dalam penelitian ini adalah responden yang memiliki pohon gaharu di Desa Pulau Gadang dan Desa Kota Mesjid. Adapun responden yaitu merupakan anggota kelompok tani di Desa Pulau Gadang sebanyak 17 orang dan di Desa Koto Mesjid sebanyak 10 orang. 
Teknik Pengumpulan Data

Pengambilan data dilakukan secara langsung di lapangan sebagai berikut :

1. Identifikasi masyarakat yang melakukan pengelolaan tanaman dengan sistem agroforestry dan melakukan penanaman maupun pemeliharan pohon gaharu dengan cara observasi. Observasi merupakan pengamatan atau survei dilapangan. Kegiatan observasi yang dilakukan yaitu pengukuran diameter untuk pohon gaharu.

2. Wawancara dan Kuesioner terhadap masyarakat yang melakukan pengelolaan dengan sistem agroforestry yaitu pengukuran gaharu yang dilakukan berdasarkan luas lahan yang dimiliki oleh petani. Wawancara adalah tanya jawab lisan antara dua orang atau lebih secara langsung untuk menggali informasi dari tiap individu.

3. Studi pustaka/dokumentasi

Dokumentasi dapat berupa foto lahan agroforestry dan tanaman gaharu yang dikelola.

\section{Pengolahan Data}

Data yang diperoleh kemudian diolah dengan melakukan perhitungan rata - rata diameter pohon. Adapun perhitungan rata-rata diameter dilakukan dengan cara sebagai berikut:

$$
\mathbf{D}=\frac{\boldsymbol{\Sigma} \mathbf{D}}{\boldsymbol{N}}
$$

Keterangan:

$\mathrm{D}=$ Rata-rata diameter $(\mathrm{cm})$

$\Sigma \mathrm{d}=$ Jumlah diameter pohon $(\mathrm{cm})$

$\mathrm{n}=$ Jumlah Pohon

Adapun perhitungan jumlah pohon per $\mathrm{Ha}$ menggunakan rumus sebagai berikut:

$$
\text { Jumlah pohon } / \mathrm{Ha}=\frac{\sum \mathrm{N} \text { (pohon) }}{\text { Luas Lahan }(\mathrm{Ha})}
$$

\section{Analisis Data}

Data yang telah di kumpulkan tersebut dianalisis secara deskriptif kualitatif terhadap kondisi kepemilikan, luasan lahan agroforestri serta potensi gaharu dengan terlebih dahulu ditabulasi dan dirata-ratakan berdasarkan keberadaan kelompok tani gaharu.

\section{HASIL DAN PEMBAHASAN}

\section{Potensi Tanaman Penghasil Gaharu}

Pengelolan tanaman penghasil gaharu memiliki tujuan selain menjaga keseimbangan ekosistem tetapi juga dapat dijadikan sebagai sumber ekonomi masyarakat. Adapun potensi tanaman penghasil gaharu yang dikelola oleh masyarakat dapat dilihat pada tabel 1 berikut. 
Tabel 1. Potensi Tanaman Penghasil Gaharu di Desa Pulau

Gadang dan Desa Koto Mesjid

\begin{tabular}{ccccc}
\hline \multirow{2}{*}{$\begin{array}{c}\text { Umur } \\
\text { Pohon } \\
\text { (Tahun) }\end{array}$} & \multicolumn{2}{c}{$\begin{array}{c}\text { Desa Pulau } \\
\text { Gadang }\end{array}$} & \multicolumn{2}{c}{ Desa Koto Masjid } \\
\cline { 2 - 5 } & $\begin{array}{c}\text { Rata- } \\
\text { rata(cm) }\end{array}$ & $\begin{array}{c}\text { Jumlah } \\
\text { Batang }\end{array}$ & $\begin{array}{c}\text { Diameter } \\
\text { Rata-rata } \\
\text { (cm) }\end{array}$ & Jumlah \\
& & & & \\
\hline 7 & 9,11 & 70 & 6,99 & 100 \\
8 & 9,14 & 920 & 9,03 & 300 \\
9 & 9,04 & 440 & 9,15 & 400 \\
\hline
\end{tabular}

Sumber: Data Olahan, 2017

Berdasarkan Tabel 1 diatas, diketahui jenis tanaman penghasil gaharu pada Desa Pulau Gadang dan Desa Koto Masjid terdapat pada umur 7, 8, dan 9 tahun. Tanaman penghasil gaharu yang dikelola oleh masyarakat Desa Pulau Gadang didominasi pada umur 8 tahun sebanyak 920 batang dengan rata-rata diameter $9,14 \mathrm{~cm}$. Sedangkan pada masyarakat Desa Koto Mesjid lebih banyak mengelola tanaman penghasil gaharu pada umur 9 tahun sebanyak 400 batang dengan rata-rata diameter $9,15 \mathrm{~cm}$. Adapun potensi tanaman penghasil gaharu berdasarkan rata-rata diameter dapat dilihat pada gambar 1 .

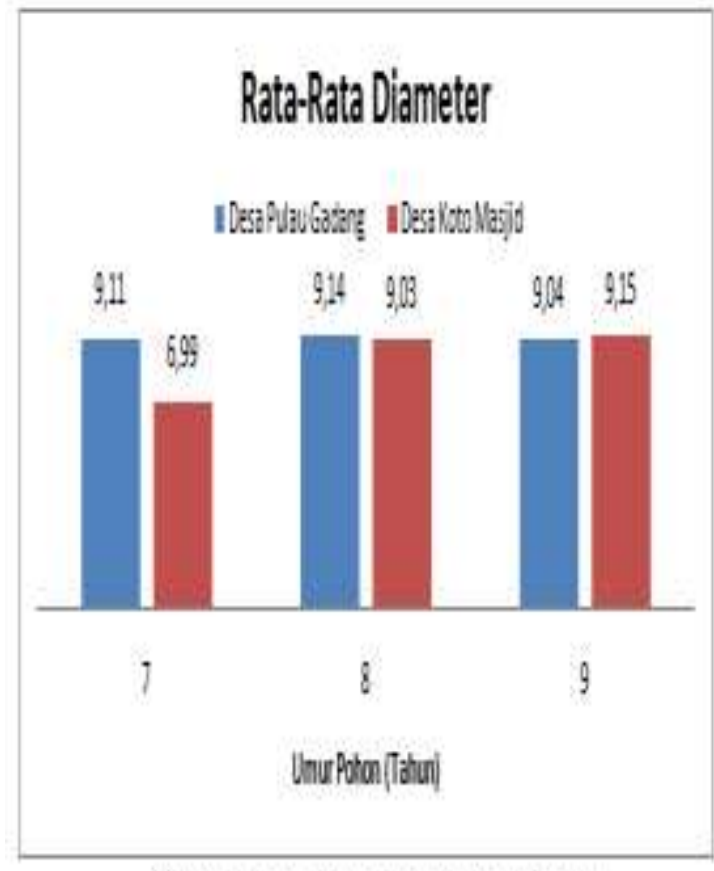

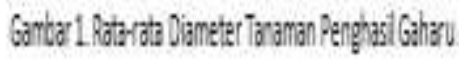

Menurut, Tourney \& Korstia (1974) dalam Simorangkir (2000) menyatakan bahwa pertumbuhan diameter tanaman berhubungan erat dengan laju fotosintesis yang akan sebanding dengan jumlah intensitas cahaya matahari yang diterima dan respirasi.

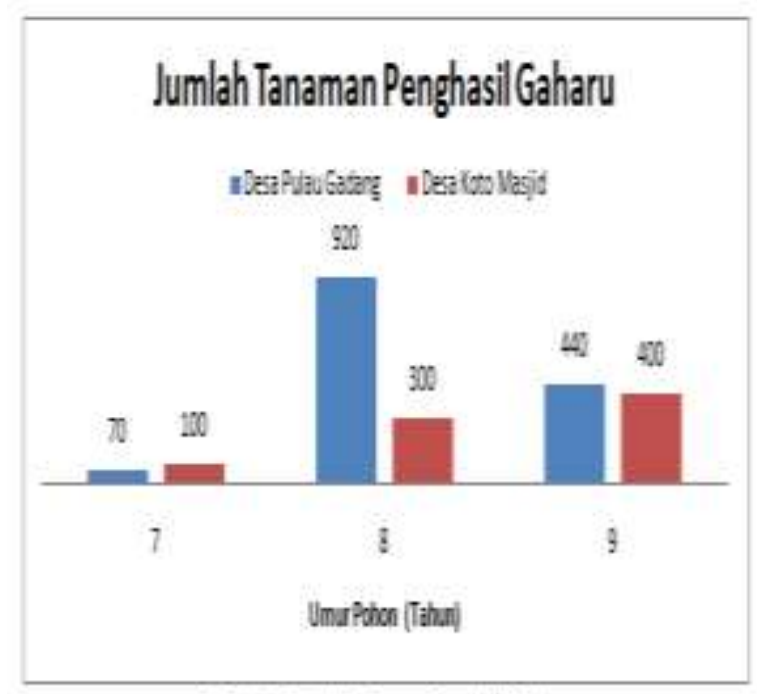

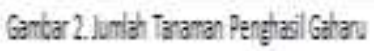


Pada Gambar 2 diketahui potensi tanaman penghasil gaharu didominasi usia 8 tahun pada tahun tanam 2009 pada Desa Pulau Gadang. Sementara itu, di Desa Koto Masjid di dominasi pada usia 9 tahun pada tahun tanam 2008. Sementara itu, pada umur 7 tahun memilik jumlah tanaman yang paling sedikit yaitu 70 batang di Desa Pulau Gadang dan 100 batang di Desa Koto Masjid. Rendahnya jumlah tanaman pada usia 7 tahun diketahui merupakan tanaman sisipan yang dilakukan oleh masyarakat dalam menyulam tanaman penghasil gaharu yang mati pada tahun tanam sebelumnya.

Kepemilikan lahan yang ada di Desa Pulau Gadang bervariasi antar 11,5 ha /petani yang ditanami gaharu yang sistem penanamannya menggunakan agroforestri seperti tanaman karet, durian, coklat dan sebagainya. Tanaman yang dominan adalah pohon karet yang merupakan salah satu sumber pendapatan petani di Desa Pulau Gadang
Tabel 2. Rata-rata Pohon/Ha pada Desa Pulau Gadang

\begin{tabular}{|l|c|c|c|}
\hline \multicolumn{1}{|c|}{ Nama } & Luas & Ipohon & Pohon/Ha \\
\hline Harmoko & 1 & 100 & 100 \\
\hline Wahyono & 1 & 70 & 70 \\
\hline Muslimin & 1 & 70 & 70 \\
\hline $\begin{array}{l}\text { Dian } \\
\text { Andhika }\end{array}$ & 1 & 100 & 100 \\
\hline Asnarin & 1 & 70 & 70 \\
\hline Sopyan .E & 1 & 90 & 90 \\
\hline Muhtaridi & 1 & 80 & 80 \\
\hline Fauzi & 1 & 70 & 70 \\
\hline Aman P & 1 & 50 & 50 \\
\hline Iril & 1 & 80 & 80 \\
\hline Jamaludin & 1 & 100 & 100 \\
\hline Anto & 1 & 100 & 100 \\
\hline Erwin Pito & 1,5 & 120 & 80 \\
\hline Olil & 1 & 70 & 70 \\
\hline Israel & 1 & 70 & 70 \\
\hline Japrizal & 1,5 & 120 & 80 \\
\hline Panid & 1,5 & 70 & 46,67 \\
\hline Jumlah & 18,5 & 1430 & 1280 \\
\hline Rata-rata & 1,09 & 84,12 & 78,03 \\
\hline
\end{tabular}

Sedangkan untuk Desa Koto Masjid memiliki luas lahan lebih kecil karena petani yang melakukan penanaman gaharu dengan pola agroforestri lebih sedikit. 
Tabel 3. Rata-rata Pohon/Ha pada Desa Koto Masjid

\begin{tabular}{|l|c|c|c|}
\hline \multicolumn{1}{|c|}{ Nama } & Luas & $\sum$ pohon & Pohon/Ha \\
\hline Sarul & 1,5 & 120 & 80 \\
\hline Agus & 1 & 80 & 80 \\
\hline Asril Idris & 1 & 90 & 90 \\
\hline Yurnalis & 1 & 50 & 50 \\
\hline Zulkifli & 1,5 & 100 & 66,67 \\
\hline Khairil & 2 & 80 & 40 \\
\hline Anas & 1 & 50 & 50 \\
\hline Mushelmi & 1 & 50 & 50 \\
\hline Saripah & 1 & 80 & 80 \\
\hline Midi & 1 & 100 & 100 \\
\hline Jumlah & 12 & 800 & 686,67 \\
\hline Rata-rata & 1,2 & 145,45 & 68,67 \\
\hline
\end{tabular}

Berdasarkan Tabel 2, diketahui pada masyakat Desa Pulau Gadang rata-rata luas lahan yaitu 1,09 $\mathrm{Ha}$ /petani, rata - rata jumlah pohon penghasil gaharu sebesar 84,12 pohon/petani, dan rata-rata pohon/ $\mathrm{Ha}$ sebanyak 78,03 pohon/ $\mathrm{Ha} /$ petani. Sedangkan pada Desa Koto Masjid rata-rata luas lahan yaitu $1,2 \mathrm{Ha} /$ petani, rata-rata jumlah pohon 145,45 pohon/petani, dan ratarata pohon/Ha sebanyak 68,67 pohon/Ha/petani.

\section{Pola Tanaman Penghasil Gaharu}

Pola tanam gaharu dengan sistem campur ini juga sudah mulai banyak dilakukan pada beberapa daerah lain dan dengan jenis tanaman penghasil gaharu.

Pola tanam campur antara tanaman karet yang berbeda dengan $A$. malaccensis terdapat di Kabupaten Banyuasin - Sumatera Selatan, Kabupaten Merangin-Jambi (Sofyan et al. 2010), campuran Aquilaria spp dengan tanaman karet atau kakao terdapat di Propinsi Bengkulu (Wiriadinata dkk., 2010), sedangkan campuran antara tanaman karet dengan A. microcarpa terdapat di SarolangunJambi (Wiriadinata, 2004 dalam Wiriadinata dkk., 2010). Adapun jenis tanaman pokok masyarakat Desa Pulau Gadang dan Desa Koto Masjid adalah sebagai berikut.

\section{Tabel 3. Jenis Tanaman campuran}

\section{Masyarakat}

Jenis Desa Pulau Desa Kota

Tanaman Gadang (Btg) Masjid(Btg)

\begin{tabular}{lcc}
\hline Karet & 6.975 & 3.880 \\
Rambutan & 27 & 35 \\
Durian & 175 & 80 \\
Jengkol & 29 & 68 \\
Sawit & 55 & 25 \\
Kelapa & 30 & - \\
Coklat & 30 & - \\
Pinang & - & 30 \\
Gaharu & 1.430 & 800 \\
\hline
\end{tabular}


Berdasarkan tabel 3 diatas dengan masyarakat Desa Koto Masjid. diketahui Desa Pulau Gadang Tingginya pengelolaan hutan rakyat juga mengelola lebih banyak tanaman didukung dengan keberadaan jumlah penghasil gaharu yaitu sebesar 1.430 batang. Sedangkan Desa Koto Masjid mengelola sebanyak 800 batang tanaman pengahasil gaharu.

Pola tanaman campuran antara tanaman gaharu dan tanaman pokok masyarakat disebut juga dengan sistem agroforestri. Oleh karena itu, selain mempertahan nilai ekologis maupun nilai konservasi tanah tetapi juga dapat memaksimalkan pemanfaatan nilai ekonomi pada pengelolaan lahan masyarakat.

\section{Tabel 4. Perbandingan Potensi}

Tanaman Penghasil Gaharu dan Tanaman Campuran

\begin{tabular}{lccc}
\hline Nama & $\begin{array}{c}\text { Jumlah } \\
\text { Tanaman } \\
\text { Gaharu } \\
\text { (Batang) }\end{array}$ & $\begin{array}{c}\text { Jumlah } \\
\text { Tanaman } \\
\text { Campuran } \\
\text { (Batang) }\end{array}$ & $\begin{array}{c}\text { Jumglah } \\
\text { Kelompoka }\end{array}$ \\
Tani(Org)
\end{tabular}

Sumber: Data Olahan, 2017

Berdasarkan Tabel 4 diatas diketahui bahwa pengelolaan hutan rakyat berdasarkan jumlah tanaman yang dimiliki masyarakat Desa Pulau Gadang lebih besar bila dibandingkan anggota kelompok tani pada Desa Pulau Gadang yaitu berkisar 17 orang. Sedangkan, pada Desa Koto Masjid hanya 10 orang. Semakin banyak jumlah anggota kelompok tani maka akan mempengaruhi banyaknya luasan lahan dan jumlah tanaman yang dimiliki Kehutanan melalui kelompok tani yang dibentuk pada masing-masing desa.

\section{Pengelolaan Tanaman Penghasil Gaharu}

\section{Pengadaan Bibit}

Perolehan bibit tanaman penghasil gaharu bersumber dari bantuan yang diberikan oleh Dinas kehutanan yang mampu memberikan nilai ekonomi kepada masyarakat.

\section{Penanaman}

Pengelolaan tanaman penghasil gaharu yang dilakukan oleh masyarakat dimulai sejak tahun 2008 yang berawal dari kegiatan sosialisasi yang dilakukan oleh pemerintah maupun dinas terkait dalam memberikan solusi tanaman. 


\section{Pemeliharaan}

Pemeliharaan pada umumnya meliputi pemberian pupuk dan pembersihan gulma. Tanaman kehutanan yang pada umumnya tidak memerlukan biaya yang banyak dalam perawatan menjadikan minimnya biaya yang dikeluarkan dalam pemeliharaannya.

\section{Pemanenan}

Pemanenan tanaman penghasil gaharu dilakukan tidak hanya memanfaatkan gubal gaharu tetapi juga kayu gaharu. Tetapi, pada Desa Pulau Gadang dan Desa Koto Masjid Desa Pulau Gadang dan Desa Koto Masjid belum dilakukan pemanenan. Hal ini terlihat belum adanya bentuk hasil panen berupa produk gaharu dan kegiatan pemanenan yang dilakukan oleh masyarakat.

\section{KESIMPULAN DAN SARAN}

\section{Kesimpulan}

Adapun kesimpulan dari hasil penelitiaan diatas adalah sebagai berikut:

1. Potensi tanaman penghasil gaharu di Desa Pulau Gadang yaitu pada usia tanam 7 tahun sebanyak 70 batang, 8 tahun sebanyak 920 batang dan 9 tahun sebanyak 440 batang. Sedangkan, Desa Koto Masjid yaitu pada usia tanam 7 tahun sebanyak 100 batang, 8 tahun sebanyak 300 batang dan 9 tahun sebanyak 400 batang.

2. Potensi tanaman penghasil gaharu pada masyakat Desa Pulau Gadang dengan rata-rata luas lahan yaitu 1,09 Ha/petani, rata - rata jumlah pohon penghasil gaharu sebesar 84,12 pohon/petani, dan rata-rata pohon/Ha sebanyak 78,03 pohon/Ha/petani. Sedangkan pada Desa Koto Masjid dengan rata-rata luas lahan yaitu 1,2 $\mathrm{Ha}$ /petani, ratarata jumlah pohon 145,45 pohon/petani, dan rata-rata pohon/Ha sebanyak 68,67 pohon/Ha/petani.

3. Pola tanam yang digunakan oleh masyarakt Desa Pulau Gadang dan Koto Masjid adalah campuran. Jenis tanaman yang dikelola oleh masyarakat Desa Pulau Gadang adalah Karet, Rambutan, Durian, Jengkol, Sawit, Kelapa, Coklat dan Gaharu. Sedangkan pada Desa Koto Masjid adalah Karet, Rambutan, Durian, Jengkol, Sawit, Pinang dan Gaharu. 


\section{Saran}

Saran yang dapat diberikan adalah perlu adanya jarak tanam yang jelas pada tanaman penghasil gaharu sehingga tidak mengganggu pertumbuhan dari tanaman penghasil gaharu tersebut.

\section{DAFTAR PUSTAKA}

Santoso, E., D. Purwito, Pratiwi, G. Pari, M. Turjaman, B. Leksono, A.Y.P.B.C. Widyatmoko, R.S.B. Irianto, A. Subiakto, T. Kartonowaluyo, Rahman, A. Tampubolon, S. A. Siran. 2012. Master Plan Penelitian dan Pengembangan Gaharu Tahun 2013-2023. Kementerian Kehutanan. Badan Litbang Kehutanan. Puslitbang Konservasi dan Rehabilitasi. Bogor.

Simorangkir, B.D.A.S. 2000. Analisis Riap Dryobalanops lanceolata Burc pada Lebar Jalur yang Berbeda di Hutan Koleksi Universitas Mulawarman Lempake. Frontir Nomor 32. Kalimantan Timur

Sofyan, A., A. Sumadi, A. Kurniawan, A. Nurlia. 2010. Pengembangan dan Peningkatan Produktivitas Pohon Penghasil Gaharu Sebagai bahan Obat di Sumatera. Laporan Hasil Penelitian Program insentif Peningkatan Kemampuan Peneliti dan Perekayasa. Kementerian Kehutanan. Balai Kehutanan Palembang. Tidak dipublikasian.

Suharti, S. 2010. Prospek Pengusahaan Gaharu Melalui Pola Pengelolaan Hutan Berbasis Masyarakat
(PHBM). Info Hutan Vol. VII No. 2:141-154,2010.

Suhartati, A. Wahyudi. 2011. Pola Agroforestry Tanaman Penghasil Gaharu dan Kelapa Sawit. Jurnal Penelitian Hutan dan Konservasi Alam Vol. 8, No. 4: 363-371.

Stevanus, N.T. 2014. Budidaya Pohon Penghasil Gaharu (Aquilaria malaccensis) di Kenagarian Pilubang, Kecamatan Harau, Kabupaten 50 Kota, Provinsi Sumatera Barat. Jurnal Nasional Ecopedon Vol. 1, No. 1: 001-004.

Wiriadinata, H., G. Semiadi, D. Darnaedi, E. B. Waluyo. 2010. Konsep Budidaya gaharu (Aquilaria spp.) di Provinsi Bengkulu. Jurnal Penelitian Hutan dan Konservasi Alam Vol. VII, No. 4:371-380 